\title{
Memoria, experiencia y cuerpo \\ en crónicas franciscanas del siglo XVT: \\ la construcción del natural mesoamericano
}

\section{Memory, Experience and Body in Sixteenth- Century Franciscan Chronicles: \\ The Construction of the Mesoamerican Natural}

\author{
Óscar Fernando López Meraz* \\ Universidad Veracruzana \\ México
}

Correo:sthi2009@live.com.mx

DOI 10.48I02/hyg.vi54.296

ABSTRACT

The chronicles of the conquest of America have been revalued as historical sources in recent decades, and this text follows that revisionism to interpret and identify in Western memory-experience communion the key to descriptions of the Mesoamerican natural. It is argued that the body is the axis of the narration about the other in two axes: one related to the friars as witnesses who could not communicate their experience away from the canon produced by the cultural framework to which the indigenous it is described, for incorporation into the salvation history, as a subject historically constituted as close to the Christian worldview, even in passages where documents are constructed with the participation of indigenous informants.

Key words: Rethoric, Historiography, Otherness, Emotions, Salvation History.

\section{Resumen}

Las crónicas de la conquista de América han sido revaloradas como fuentes históricas en las últimas décadas, y este texto sigue ese revisionis-

* Agradezco el apoyo recibido del Conacyt para la realización de este trabajo por medio de la Beca Posdoctoral 2018-2019. 
mo para interpretar e identificar en la comunión memoria-experiencia occidental la clave de las descripciones sobre el natural mesoamericano. Se sostiene que el cuerpo es el eje de la narración sobre el otro en dos ejes: uno relacionado con los frailes como testigos que no pudieron comunicar su experiencia alejada del canon producido por el marco cultural al que pertenecían, y otro en el que el indígena es descrito, para su incorporación en la historia salvífica, como un sujeto constituido históricamente como cercano a la cosmovisión cristiana, incluso en pasajes donde los documentos son construidos con la participación de informantes indígenas.

Palabras clave: retórica, historiografía, otredad, emociones, historia salvífica.

Artículo recibido: 3/09/2019

Artículo aceptado: I I/Io/2019

\section{INTRODUCCIÓN}

T as crónicas de la conquista de América han sido revaloradas su lógica interna y la mejor comprensión de su marco contextual han contribuido de manera significativa a ello. Los acercamientos desde el discurso han permitido reconocer a estas obras como organizaciones retóricas, y como tales, no portadoras de conocimientos objetivos, sino simbólicos. El presente documento parte de esta interpretación e identifica en la comunión memoria-experiencia occidental la clave de las descripciones sobre el natural mesoamericano.

Se sostiene que el cuerpo es el eje de la narración sobre el otro en dos ejes: uno relacionado con los frailes como testigos que no pudieron comunicar su experiencia alejada del canon producido por el marco cultural al que pertenecían, donde los sentidos y las emociones fueron incorporadas a la narración para cumplir las expectativas de los receptores, y otro en el que el indígena es descrito, para su incorporación en la historia salvífica, como un 
sujeto constituido históricamente como cercano a la cosmovisión cristiana, incluso en pasajes donde los documentos son construidos con la participación de informantes indígenas.

De esta manera, no se comparte el supuesto de la construcción de una etnografía desarrollada muy temprano por los religiosos, sino de una narración interesada en fundar una cristiandad indígena para la cual es necesario inventar, al menos, una parte del pasado precristiano en su intento de acercar con mayor profundidad a los nuevos catecúmenos a la fe en Cristo. Este supuesto requerirá atender los siguientes cuestionamientos: ¿cómo se comunican memoria y experiencia en el momento histórico de la escritura de las crónicas? y ¿de qué manera la relación entre memoria y experiencia participó en la narración franciscana sobre el indígena?

Para atenderlas, el artículo se ha organizado en cuatro apartados. En el primero se desarrolla la comprensión de las crónicas como narraciones descriptivas de corte simbólico; en el segundo se profundiza en cómo la memoria participó en el acercamiento con la otredad; después se trabaja el concepto de experiencia y se adelanta cómo se relaciona con la memoria en crónicas; y, por último, se pone atención en cómo la teoría del cuerpo se presentó en los frailes, y cómo construyeron tópicos relacionaos con él para dar cuenta de los indígenas en sus comunicaciones.

\section{CRÓNicas de la CONQUista:}

NARRACIONES DESCRIPTIVAS SIMBÓLICAS

Las crónicas de la conquista de América presentan un carácter narrativo indudable: cuentan cosas. Esto en primera instancia, pues lo que realmente comunican son significados. El acontecimiento (real o ficticio) se fija en el discurso, y el lector/oyente lo percibe en condiciones histórico-espaciales de inscripción. A esta dialéctica fundamental del discurso (evento-significado) posibi- 
litadora de la escritura, es necesario sumar la correspondiente a sentido-referencia porque gracias a ella se presenta el contenido siempre estructurado y la proyección del mundo en el que está situado el qué del discurso. ${ }^{1}$

Cada integrante de la última pareja propone acercamientos distintos: la primera está relacionada con la explicación y está vinculada con la semiótica, mientras que la segunda caminaría hacia la interpretación y, por tanto, a un ejercicio hermenéutico. Es importante mencionar esto porque más que seguir una u otra vía, aquí se tomarían ambas posiciones entrelazadas para analizar crónicas franciscanas del siglo XVI.

$\mathrm{Al}$ respecto, lo primero que habría que decir es que no se concibe sólo al texto como el único concepto operatorio ni se acepta que esté aislado de su contexto. De la semiótica, básicamente la propuesta por la corriente greimasiana, ${ }^{2}$ se recuperará la noción de enunciador (el cronista) que produce (o está interesado en hacerlo) un efecto de sentido de Verdad. Por su parte, la hermenéutica permitiría reconstruir algunas de las condiciones de producción presentes en la redacción de los textos a analizar, como las relaciones de los sentidos en la descripción de los naturales mesoamericanos y algunas emociones; el cuerpo del cronista será uno de los dos puntos fundamentales de este ejercicio, siendo el otro la construcción del cuerpo del "vencido".

Pero ¿cómo se puede observar el mundo proyectado al que pertenecen las crónicas? Daremos una respuesta sencilla: existen en ellas referencias liberadas que permiten reconstituirlo o acercarse a él. Tomaremos para ello algunas precauciones. Lo primero será partir de que son comunicaciones retóricas y como tales su objetivo no fue decir la verdad en el sentido moderno

\footnotetext{
${ }^{1}$ Raquel Gutiérrez, “Acerca de la crónica”, p. 239. Cabe mencionar que este apartado sigue muy de cerca lo expresado por esta autora.

${ }^{2}$ Greimas propone reemplazar el concepto “intención” por el de "intencionalidad”. A. J. Greimas y J. Courtés, Semiótica. Diccionario razonado de la teoría del lenguaje.
} 
que la relaciona con la objetividad, sino que pertenecen a una red construida por los frailes con intenciones simbólicas. El evento siempre descrito desde las experiencias de los individuos que cuentan es trascendente por el significado otorgado desde la cultura a la que pertenecen y para la cual escriben, una donde memoria y experiencia son fundamentales para la construcción de textos con "sentido de verdad".

$\mathrm{Al}$ respecto vale la pena recordar que la retórica se centró en el código persuasión/no persuasión basado en la concepción moralizante correcto/incorrecto para juzgar los modales y las conductas apropiadas en sociedades estratificadas, como la medieval y la colonial; de ahí que la realidad en las crónicas de la conquista es moral y no cognitivo-objetiva. Por supuesto que los discursos retóricos producen conocimiento, pero éste es moralizante y ejemplar, por lo que las crónicas no ofrecen conocimiento singular de los acontecimientos históricos. Edmundo O’Gorman insistía permanentemente en no buscar información en los relatos de la conquista de México del siglo Xvi, sino tratar de someterla a crítica en función del contexto que la genera, para acercarse a lo que dichos relatos significaron en su época. ${ }^{3}$ Hace poco, Perla Chinchilla ${ }^{4}$ ha llamado a las producciones como las que se traba-

3 ¿Por qué no usar un concepto distinto a conocimiento cuando se habla de retórica, y de esta manera reservarlo para la ciencia? Se prefiere conservar el término de "conocimiento", de acuerdo con Mendiola, para la retórica por dos razones: a) porque a pesar de que el conocimiento no se había automatizado o diferenciado de otras funciones para la sociedad europea anterior a finales del siglo XVII, la retórica era el medio para producir conocimientos y en consecuencia se interesaría por que el lector actual se diera cuenta de que aquello que la modernidad llama arte, es semejante a lo que la sociedad anterior denominaba conocimiento; $y, b)$ para respetar la autorreferencialidad de los sistemas; esto es, antes de que naciera la ciencia la retórica se describía a sí misma como productora de conocimientos, y no como será después, como pura ornamentación. Alfonso Mendiola, "Relatos de la conquista, retórica y referencia”, pp. 113-146. ${ }^{4}$ Perla Chichilla, Expediente "Formas discursivas", Historia y Grafía, núm. 43, julio-diciembre, 2014. La autora reconoce como antecedente el "Expediente" en el que participaron, en el número 32 (2009) de la misma revista, Hans E. Bödeker, Luiz Costa Lima, Hans Ulrich Gumbrecht, Alfonso Mendiola y Hayden 
jan aquí "formas discursivas literarias", lo que permite dejar de observar la producción escriturística de la época novohispana bajo una misma, única e invariable forma, y reconoce una participación importante de la oralidad en los discursos.

Además, no puede perderse de vista que existe una fuerte relación entre oralidad y escritura. Las crónicas son textos que intentan ofrecer la posibilidad de estar ahí y escuchar los relatos de los protagonistas. Sería tarea del interesado conocer las intencionalidades de ese mundo ausente para el lector contemporáneo. De momento, adelantemos que será mediante la descripción mediada por tiempos verbales y la designación de lugares apoyada por adverbios, entre otros recursos lingüísticos, los que posibiliten el mencionado efecto de veracidad basado en gran medida por haber estado ahí, en el momento de los hechos. Ser testigo será considerado fundamental en los relatos con aspiración de "verdad".

Y éste es un interés explícito por parte de los autores de crónicas de conquista, como lo refleja el título del libro atribuido a Bernal Díaz del Castillo: Historia verdadera de la conquista de la Nueva España. Si bien esto podría ser considerado un caso excepcional en lo que corresponde a la rápida identificación de adjudicarse el supuesto de verdad, es frecuente que dentro de las obras existan polémicas basadas en decir que tal o cual autor miente o está equivocado. Sobre esto pueden observarse las querellas entre el mismo Bernal con quienes no han pisado tierra americana y hablan sobre ella y sus habitantes (como Francisco López de Gómara), o las polémicas entre Las Casas y Sepúlveda. El mismo Fernández de Oviedo utiliza los conceptos de "fábula", "novela"

\footnotetext{
White, en donde se desarrolló la reflexión sobre lo que entonces se denominó "géneros históricos".

${ }^{5}$ El debate sobre la "ficción" y la "verdad" etnográfica se ha agudizado con la antropología posmoderna en la actualidad. Para ello puede verse El antropólogo (1989), de Clifford Geertz, y Writting Culture: The Poetics and Politics of Ethnography (1986), de James Clifford.
} 
y "mentira" para descalificar los escritos de sus rivales. El discurso en el que se inserta la crónica no es el de ficción, sino uno narrativo con pretensiones de verdad.

El tema aquí será acercarse a una parte de la maquinaria utilizada para producir ese efecto. La referencia a las Sagradas Escrituras, los padres de la Iglesia y el mundo grecorromano le permite al autor construir un marco común con el lector/escucha. A ello deberá agregarse la intencionalidad del enunciador de corresponder a las expectativas del destinatario, lo que le exige a aquél no sólo identificarse como poseedor de la "verdad", sino fundamentar su dicho. Esto se pudo lograr en gran medida por la incorporación de la experiencia personal y hacerla viva, así como la referencia a hechos cercanos en el presente. Gracias a ello se produce la coincidencia en un universo axiológico compartido entre el emisor y el receptor, posibilitando observar qué hay afuera o alrededor del texto, pero le corresponderá a éste decidir si cree o no en lo que se le cuenta.

Esto lleva por necesidad a pensar en el trabajo de Paul Ricoeur, particularmente en el ejercicio de Mímesis III. Ésta es definida como la "intersección entre el mundo del texto y el mundo del lector". ${ }^{6}$ Mímesis III será entonces, para nuestro caso, la comunicación del mundo construido en la crónica con la participación del mundo del lector en el momento de su producción. Siendo la experiencia el eje articulador del discurso en un contexto donde la retórica fue la forma de construcción y comunicación del saber.

Para el sistema observador, afirma Mendiola, ${ }^{7}$ existen dos posibles nociones de experiencia: una cognitiva y otra normativa. La segunda, que desarrollan los frailes, funciona cuando no rehace la estructura de la expectativa decepcionada, sino que la conserva por ser valiosa para la sociedad. El sujeto que la experimenta no

\footnotetext{
${ }^{6}$ Paul Ricoeur, Tiempo y narración, p. 83.

${ }^{7}$ Alfonso Mendiola, Retórica, comunicación y realidad: la construcción retórica de las batallas en las crónicas de la conquista, p. 145.
}

Memoria, experiencia y cuerpo en crónicas franciscanas del siglo xvı / 19 
puede modificarla porque cohesiona, pues son conocimientos que no deben ser puestos en duda, y desarrolla su descripción a partir del deber ser. Para el caso que abordamos, los conocimientos que no pueden cuestionarse son los teológicos, mismos que deben guiar la experiencia con lo novedoso.

En la sociedad española del siglo xvı, "la experiencia depende de la acción y, en esta clase de expectativa, la acción se observa por medio del esquema binario norma/desviación de la norma”. ${ }^{8} \mathrm{La}$ experiencia del hombre del siglo xvi funciona normativamente, lo que significa que la experiencia del mundo está sometida en primera instancia a la moralidad -cristiana- y mucho menos a la cognición. Ante una realidad que se abre a los sentidos, a la vista y la audición sobre todo, y que se debería reconocer como diferente, el mecanismo retórico hace lo contrario: valora lo ajeno a partir de lo propio, y le impone sus juicios.

Concluyamos esta sección, que pretender ser parte del marco teórico para la interpretación de nuestro tema, con algunas afirmaciones. En primer lugar, los autores de las crónicas buscaron relatar su experiencia por diferentes razones, pero esa intención construye lo que Raquel Gutiérrez llama "estructura pre-narrativa de la experiencia”. Ello permite la existencia de un alto grado de oralidad para construir el efecto de estar ahí, en lo que se cuenta.

De esta manera, comparte una experiencia que si bien presenta novedad ésta es domesticada a partir de valores simbólicos que facilitan su comprensión en un horizonte específico. El relato comunica un mundo que se cierra con la experiencia del lector, la cual está inserta en el discurso. Existe una intencionalidad declarada en construir relatos de verdad que permitan rescatar la experiencia particularmente con el otro del olvido. Ésta, sin embargo, también estará dirigida a la fundación de un ser diferente al occidental-cristiano al que intenta sumar a la historia salvífica por medio de dos recursos básicos: mostrar la superioridad cultural

${ }^{8}$ Ibidem, p. 149. 
del vencedor, y traducir al otro en un precristiano para construir una memoria que justifique la participación evangelizadora. Sobre esto se profundizará a continuación.

\section{El ACERCAMIENTO A LA OTREDAD POR EL DISPOSITIVO DE LA MEMORIA}

Arriba se ha mencionado que el cronista narra significados a partir de su experiencia, pero ¿existiría alguna diferencia si lo que cuenta sucedió o no? En nuestra opinión no resulta algo que marque un cambio sustancial, pues el autor inventa en un marco específico de producción de verdad y espera comunicar símbolos al receptor. Todorov opina: "Un hecho pudo no haber ocurrido, contrariamente a lo que afirma un cronista determinado. Pero el que éste haya podido afirmarlo, que haya podido contar con que sería aceptado por el público contemporáneo, es algo por lo menos tan revelador como la simple ocurrencia de un acontecimiento".?

Pero ¿y cuando se habla de los otros sucede lo mismo? Es decir, ¿sigue siendo el autor el único que existe en el discurso? Al menos para los documentos que nos interesa analizar (crónicas franciscanas del siglo Xvi) pensamos que sí en gran parte de lo producido. Y sucede porque, aun con la participación "directa" del otro como informante y/o traductor, sigue siendo el fraile el que dirige y construye un marco de referencia, sin mencionar que ninguno de los indígenas podría dar cabal información del mundo mesoamericano precortesiano, pues ese pasado habría de ser perseguido, destruido, y ellos formados en la cosmovisión cristiana. ${ }^{10}$

\footnotetext{
${ }^{9}$ Tzvetan Todorov, La conquista de América, el problema del otro, p. 60.

${ }^{10}$ Una problemática central sería la de la credibilidad de las fuentes de las que se habla aquí, particularmente cuando, en ocasiones, la información es confirmada por la arqueología. En un trabajo posterior se analizará el papel de las crónicas en el desarrollo de la etnografía contemporánea más allá del dato arqueológico, recuperando, entre otros, los ejercicios desarrollados por Danièlè Dehouve entre los tlapanecos de Guerrero, Saúl Millán entre los nahuas de la sierra norte de
} 
Incluso si se consideraran las acciones descriptivas de los frailes como etnográficas -ante lo que no estamos de acuerdo-, éstas sólo podrían desarrollarse desde un sujeto occidental que se presenta a sí mismo como el único capaz de ofrecer una interpretación histórica válida, ${ }^{11}$ y esto se lograría a partir de dos oposiciones semánticas presentes de modo permanente en toda descripción de la alteridad: dentro/fuera - guía de las categorías espaciales-, y nosotros/ellos - guía de las categorías culturales y, por tanto, identitarias.$-{ }^{12}$ De esta manera, es el autor quien selecciona hechos, guía el relato, responde preguntas explícitas e implícitas, ofrece su interpretación del otro por medio de un discurso que cuenta con su propia historicidad y tiene señales de expresión. ${ }^{13}$

Mediante ese proceso Occidente termina con los salvajes desde el siglo xvi. Más allá de la violencia de las armas, las epidemias que transporta o la esclavitud aplicada, su técnica, su moral y su fe, ${ }^{14}$ en lo que la palabra ocupa un lugar central, logra ese efecto. Ésta es testigo de la incapacidad por reconocer al otro tal y como es, e insiste en dejar comunicado lo que es semejante a los conquistadores. Cuando existen problemas para dar cuenta del otro, como sucede con América y sus habitantes, su identidad se

Puebla, y William Merril entre los rarámuri; y desde la Historia algunos trabajos de Alfredo López Austin y Federico Navarrete. Por lo pronto, esta acción supera el objetivo del presente trabajo.

${ }^{11}$ Michel de Certeau, L'écriture de l'histoire, hace esta crítica.

${ }^{12}$ Amodio ańade otro elemento al proceso de la construcción del Otro: una "alteridad cercana" (ustedes) y una "alteridad lejana" (ellos). Emanuele Amodio, Formas de la alteridad: construcción y difusión de la imagen del indio americano en Europa durante el primer siglo de la conquista de América.

${ }^{13}$ Una mirada comparativa resultaría esencial para conocer similitudes y diferencias tanto en el discurso occidental como en la posible "resistencia" indígena, y con ello, quizá, se abonaría en matizar la idea de un "indio imaginario" (cfr. Guy Rozat, Indios imaginarios, indios reales en lo relatos de la conquista, 1993). En este sentido, el trabajo de Eduardo Viveiros de Castro, La inconstancia del alma salvaje (2018), donde analiza obras jesuitas del siglo Xvi en el Brasil amazónico, sería uno de los imprescindibles para tal tarea. Por lo pronto, este ejercicio rebasa los objetivos de esta entrega.

${ }^{14}$ Véase Pierre Clastres, "Entre silencio y diálogo", pp. 14-16.

\section{2 / Óscar Fernando López Meraz}


resuelve simbólicamente en un ejercicio teórico-práctico. De esta forma se construye una alteridad desde el etnocentrismo donde se comunica lo desconocido por medio de lo conocido; como dijo Lewis: "el etnocentrismo es la condición humana de la alteridad". ${ }^{15}$ El ejercicio de construcción de las figuras de la alteridad ${ }^{16}$ se basa en sumar al panteón antropológico seres que nunca son tan extraños a la racionalidad que los describe, y esto sucede desde la Antigüedad.

La otredad en la modernidad temprana que sigue siendo, a nuestro parecer, un continuum de lo medieval al menos en lo relacionado con la escritura de crónicas franciscanas, ${ }^{17}$ es heredera de un ejercicio de producción del diferente. Para Marc Guillaume: "con la modernidad entramos en la era de la producción del Otro. No se trata ya de matarlo, devorarlo o seducirlo, ni de enfrentarlo o rivalizar con él, tampoco de amarlo u odiarlo; ahora, primero se trata de producirlo. El otro ha dejado de ser un objeto de pasión para convertirse en un objeto de producción". ${ }^{18}$

Esto no es un asunto menor, pues no se trata de la construcción de un otro prescindible físicamente, ${ }^{19}$ como sucede en acciones más contemporáneas como el genocidio armenio (1915-1923) o el nazi (1939-1945) y un largo etcétera, sino que el natural, para los frailes, es un sujeto esencial en su proyecto evangelizador. Para éste, sin embargo, tendrá que dejar su ser del pasado y deberá ser purificado incluso desde la escritura. El olvido del pasado del

${ }^{15}$ Apud Esteban Krotz, "Alteridad y pregunta antropológica”, p. 20.

${ }^{16}$ La expresión "figuras de la alteridad” es de Jean Baudrillard y Guillaume Marc, Figuras de la alteridad.

${ }^{17}$ Le Goff pensó en una Edad Media larga que llegaría hasta la primera mitad del siglo XviII. Cfr. Jacques Le Goff, Faut-il vraiment découper l'histoire en tranches? ${ }^{18}$ Apud José Luis Jofr, “Todas las otredades la otredad. La construcción discursiva de 'la otredad' en el acontecimiento del 11 de septiembre de 2001 en la revista Time. Una aproximación sociosemiótica”, p. 129.

${ }^{19}$ Aunque no se pueden negar la violencia física y la muerte de naturales a manos de frailes mendicantes, nos interesa decir que el proyecto franciscano requería a los indios vivos para construir una Iglesia al estilo de la "primitiva" y consolidar la evangelización novohispana. 
otro se construirá a partir de la memoria cristiana. Veamos cuáles fueron los canales utilizados para dar cuenta de un ser para el cual la experiencia occidental no tenía registros.

El asombro se apoderó de la mirada occidental al toparse con América. Una naturaleza desbordante significó una atmósfera por completo distinta, coyuntural; los sentidos se revolucionaron y se desconcertaron. A ello se le sumó la apariencia física y el desnudo de los individuos de pueblos locales, a quienes se les fue agregando en el imaginario. Esto permitió comunicaciones domesticadas por otras experiencias y tradiciones en las que se había desarrollado con claridad un discurso sobre lo bueno y lo malo, entre el nosotros y el ellos, y el adentro/afuera.

Incluso cuando existe una posición atenta a los "errores" de los autores antiguos, son éstos quienes moldean la experiencia; son ellos a los que se sigue para conocer lo nuevo. Gonzalo Fernández de Oviedo afirmó: "Mas, ¿para qué quiero traer autoridades de los antiguos en las cosas que yo he visto, ni en las que Natura enseña a todos y se ven cada día?'20 Pareciera que la experiencia se independizó de la memoria, de lo considerado por las autoridades. El historiador indiano daría un paso hacia una nueva actitud del saber, pero no sería ni suficiente ni un asunto generalizado. El argumento de autoridad es poderoso en el horizonte cultural del siglo XVI, y el pasado se valorizó para explicar y comunicar.

Este tiempo fundamental para la mentalidad occidental otorgó a la memoria, como no podía ser de otra forma, un papel protagónico, por ser indispensable para poseer la virtud de la prudencia y, a su vez, retransmitir apropiadamente los conocimientos. Su construcción partía de la unión de cadenas de significados (catena) que, al ser ordenados con sumo cuidado, conducían a la comprensión. ${ }^{21}$

${ }^{20}$ Gonzalo Fernández de Oviedo, Historia general y natural de las Indias, p. 11.

${ }^{21}$ Dichos registros constituían lo que hoy llamamos "virtualidad", espacio en el que se sitúan las construcciones discursivas medievales. La vinculación de significados se llevaba a cabo con tres planos diferentes: alegórico, metafórico y por su relación inmediata con la vida cotidiana. Las estructurales mentales debían estar 
En la memoria se recababa y clasificaba todo tipo de información. Las imágenes percibidas o configuradas a partir de los sentidos (sobre todo el de la vista) se conectaban con registros previos.

Las imágenes mentales eran la base inseparable de toda creación (inventio) y éstas, a su vez, se mantenían en continua renovación y comunicación con los sentidos. A cada registro en/de memoria le correspondía una intención (intentio), en cuyo centro se ubicaban conceptos y posibilitaba el pensamiento por medio de un proceso de creación (inventio) -literaria, filosófica o teológica- basado en la estructura mental que desempeñaba un papel activo, ya que cada creación implicaba la dilatación, ampliación y puesta en práctica del arte de la memoria relacionada con la meditación.

El proceso también incluía a la lectura, básicamente bíblica, para crear y localizar memorias, las cuales, a través de la meditación, se unían para formar discursos, y a partir de ellos aprendizajes. La escritura no pretendía subordinar a la oralidad, sino, por el contrario, buscaba perfeccionarla. La interiorización del conocimiento era tarea fundamental de la memoria. A través de este sistema de correlaciones, la memoria conforma el mundo virtual medieval e involucra en un mismo conjunto a la mente, al cuerpo y al alma. De tal forma que toda construcción medieval, en particular monástica, tiene la función de ser una máquina motivadora del pensamiento, la meditación y la creación de redes mentales de sentido, capaces de producir relaciones y conocimiento.

conectadas sistemáticamente para permitir su acceso, operación que demandaba normas precisas y uniformes. La unidad básica para dicha catalogación estaba dada por la memorización fragmentada, silábica y cíclica de los Salmos, una especie de sistema de archivo, pues permitía acceder a múltiples temáticas. La repetición sistemática de los Salmos cumplía con la función de crear un tropos y lugares comunes, con los cuales más tarde se organizaba la memoria, que establecía breves registros a partir de un significado moral (alegórico o metafórico) y un orden numérico. Cfr. Mary Carruthers, The Craft of Thought, Meditation, Rhetoric, and the Making of Images, 400-1200, p. 6. A quien se sigue en este asunto. 
Existe, además de ese proceso de construcción del conocimiento, otro relacionado con el cómo escribir. Dentro de la concepción medieval existía una diferencia importante entre texto y libro. El primero era el material necesario para componer o hacer "literatura" y constituía el medio principal para la memoria pública, mientras que el segundo era, entre otras cosas, una forma de recordar. ${ }^{22}$ Así como los sentidos recurrieron a la memoria para comprender lo que se les presentaba (un esfuerzo mental), quienes tomaron papel y pluma hicieron uso de modelos para comunicar (una intención retórica). De esta forma, aunado con la cada vez mayor lectura de autores clásicos, los autores antiguos ofrecieron mayores seguridades y sirvieron de guía en la descripción americana.

En el caso de nuestros frailes, por ejemplo, destaca la forma en que Motolinía hace suya la Atlántida de Platón y la isla que retoma de Aristóteles. La cita de autores antiguos sirve en este contexto como argumento por analogía. No se trata de una prueba en el sentido estricto, porque se habla de fenómenos desconocidos por los antiguos. Pero si ellos describen fenómenos naturales o hechos humanos que se parecen de algún modo a los que relata el cronista, éste puede hacer el puente entre el texto aprobado por la tradición y su propio texto: si es verdadero el texto antiguo, lo puede ser también el texto "moderno".

Por supuesto, el gran modelo a seguir por los escritores, especialmente religiosos, para dar a conocer lo que perciben, es la Biblia. Las referencias a Adán, Eva, Job, Noé, Moisés, o pasajes como el Apocalipsis siempre están presentes. Y, sin duda, San Agustín representó la máxima referencia para el desarrollo de la descripción de los pueblos mesoamericanos, al menos en buena parte del siglo XVI, como lo prueban las constantes referencias a este padre de la Iglesia en la obra sahaguntina.

${ }^{22}$ Ibidem, p. 8. 
El concepto de experiencia ha sido reflexionado desde hace algún tiempo por los historiadores. ${ }^{23} \mathrm{Si}$ Thompson la considera mediadora entre el ser social y la conciencia, ${ }^{24}$ Scott afirma que toda experiencia se encuentra mediada por la atribución de significado según las categorías discursivas disponibles. ${ }^{25} \mathrm{La}$ Capra ${ }^{26}$ destaca, a partir de un inventario de definiciones, algunos elementos de la experiencia, a saber: acto de poner a prueba algo, manera en que los seres humanos procesan la información, estar relacionada con la emoción o al menos con la oportunidad de entendimiento, ser sujeto consciente de un estado o una condición, o de ser conscientemente afectado por un acontecimiento, relación entre sujetos ligados de forma directa por una serie de acontecimientos, o que están vinculados a ellos a través de la memoria, de una herencia compartida. A esto puede agregarse que también existe experiencia en la memoria de un pasado que no se ha vivido de manera personal y directa. ${ }^{27}$

Por otra parte, Koselleck desarrolla lo que podría llamarse una teoría de la experiencia, en la que distingue tres tipos. ${ }^{28} \mathrm{El}$ primero se instala por sorpresa (las cosas suceden de otra manera y, además, distinta de lo que se pensaba); estas experiencias son únicas dado que el sujeto no se sorprendería de la misma forma dos

${ }^{23}$ Más allá de la historia profesional, la experiencia es un tema fundamental para el psicoanálisis, y para los enfoques fenomenológicos y existenciales de la filosofía. Edmund Husserl y Martin Heidegger, más allá de sus diferencias, postularon la experiencia vivida como objeto de reflexión filosófica, idea que luego fue retomada por pensadores tan diferentes entre sí como Henri Lefebvre, Jean-Paul Sartre y Emmanuel Levinas. De manera reciente, la historiografía ha vinculado la experiencia con el trauma destacándola en episodios bélicos, como las guerras mundiales y civiles, así como el ejercicio violento de las dictaduras.

${ }^{24}$ E. P. Thompson, Miseria de la teoría.

${ }^{25} \mathrm{~J}$. W. Scott, "Experiencia".

${ }^{26}$ Dominick La Capra, Historia en tránsito. Experiencia, identidad, teoría crítica.

${ }^{27}$ Peter Novick y Walter Benn Michaels argumentan lo contrario. Apud La Capra, Historia en tránsito, op. cit.

${ }^{28}$ Reinhart Koselleck, Los estratos del tiempo: estudios sobre la historia. 
veces, la intensidad sería más reducida, lo que produce el segundo tipo. Las experiencias se repiten y pertenecen a un proceso de acumulación donde pueden corregirse entre sí en el desarrollo de una generación. Las experiencias propias en este nivel remiten a las de los contemporáneos, y se convierten en una historia en común que pertenece, y en la que se comprende, una sociedad. Por supuesto, estos tipos de experiencia no se encuentran separados. Mientras los acontecimientos singulares, sorprendentes, evocan experiencias que dan lugar a historias, las experiencias acumuladas ayudan a estructurar a medio plazo las historias. En ocasiones, debido a condiciones y procesos específicos, las generaciones permiten la exaltación de historias personales, pero también remiten a espacios de tiempo más amplios que configuran un espacio de experiencia común. Aquí se encuentra "el espíritu de una época" ${ }^{29}$

El último nivel de experiencia se relaciona con el paso lento, el cambio de experiencia se da de a poco. Así se produce un cambio de sistema que va más allá de una persona y de una generación, y del que sólo somos conscientes retrospectivamente gracias a la reflexión histórica. Con ella, la experiencia toma un doble plano: sincrónico, como lo muestran los dos primeros niveles, y diacrónico, pues rebasa a la experiencia inmediata. El tercer tipo requiere de la comparación de experiencias de lo extraño introducidas en la propia comprensión. Por ejemplo, las historias paganas que aparecen en una perspectiva cristiana, o las historias cristianas que son reinterpretadas con las medidas de la racionalidad ilustrada. $^{30}$

\footnotetext{
${ }^{29}$ Idem.

${ }^{30}$ Un ejemplo desarrollado por Koselleck en este sentido fue el accionar de Herodoto, quien abordaba el gran tema de sus historias -las experiencias únicas y generacionales de la lucha entre los persas y los griegos- como si fueran todavía un asunto de su época, sus investigaciones se extendían dos o tres generaciones hacia un pasado que sólo podía elaborarse críticamente por medio de una experiencia ajena y mediada. El mismo reto de hacer historia -tan racional como fuera posible- de los mitos y leyendas le obligaba a incluir experiencias precedentes mediante la narración o la interpretación.
} 
Aquí pensamos que algunas de las características de la experiencia definida por los autores señalados se pueden aplicar a la acción evangelizadora de los frailes, y de modo particular en sus textos. Ellos comunican, a partir de las categorías disponibles por la episteme a la que pertenecen, su ser social y su conciencia, y con ello construyen su relación con el otro manifestada en la escritura. Como se ha visto antes, la memoria representó un factor decisivo, incluso si lo que se recuerda de ella no se vivió, pero sí se transmitió de forma intergeneracional; esa memoria también se experimenta para salir del peligro del otro, para sobrevivir.

Y con ello, fueron sujetos que no escaparon del primer tipo de experiencia pensado por Koselleck: fueron sorprendidos por lo que estaba a su alrededor y observaban de frente. Sin embargo, lo manifestado en sus escritos puede comprenderse como una experiencia "sometida" y es usada como referente de veracidad, se ha dado acumulación y correcciones en el proceso evangelizador (lo que los haría partícipes del segundo tipo de experiencia desarrollado por Koselleck).

Por lo que respecta al tercer tipo de experiencia, al menos en los cronistas franciscanos del siglo XVI e inicios del XVII, no parece haber existido ningún cambio de sistema referencial, aunque sí se podría notar una reducción del ejercicio reflexivo sobre el natural debido posiblemente al trabajo de quienes los antecedieron y a que la "novedad" se iría naturalizando en términos cristianos de manera más sistemática al reconocerles como hijos de Adán e iniciar fases de fortalecimiento en la verdadera fe. No obstante, las referencias a que los indios fueran brujos y hechiceros (con gran frecuencia bajo el nahualismo) no cesaron en todo el periodo virreinal, pero a ese proceso de sumaron otros actores como los esclavos negros y algunas de las muy variadas castas que produjo el orden colonial, como los mulatos.

Antes de pasar al siguiente apartado, dedicado al cuerpo, reflexionaremos un poco sobre los sentidos y las emociones como parte fundamental de la experiencia. Partimos de que se expre- 
san y se configuran en los planos de subjetividad construidos en un orden social y cultural, como lo indican las reflexiones, entre otros, de Norbert Elias. ${ }^{31}$ Las emociones sitúan al sujeto en interacción con otros, lo sumergen en un mundo de relaciones sociales intersubjetivas, experimentadas y vividas de manera corporal en un lugar social específico interesado con frecuencia en funcionar como un régimen de control. El carácter sintiente y sensible de los sujetos, así como su comunicación, depende de un saber afectivo condicionado por lo social. La visión del mundo está detrás y orienta a las emociones, siendo los sentidos guías de la aprehensión de la realidad. Lucien Febvre afirmó que la principal característica del hombre del siglo XVI es el sentir (¿cómo no hacerlo?) y, tal vez, se requiera volver a reflexionar ese siglo a partir de un enfoque que se detenga más en la importancia de la sensibilidad. ${ }^{32}$

¿Cómo experimentaban los sentidos y comunicaban las emociones los frailes? Intentaremos responder esta pregunta en las siguientes líneas. El pensamiento cristiano medieval integró la información registrada por los sentidos al conocimiento. San Agustín afirmó que sólo había uno, y que éste debía ser eminentemente de lo inmutable e inteligible, características de la verdad. Para el obispo africano, la verdad de los datos aportados por los sentidos resulta auténtica en el interior del alma del cognoscente. Allí al hombre se le manifiesta el poder de lo inteligible, que es eterno y no cambiante como las cosas sensibles. La existencia del mundo exterior no es negada, pero el verdadero conocimiento se logra por medio de la vía interior. Lo sensible es supeditado a la sabiduría superior.

Conocer dependía de los sentidos, pero de ellos la vista tendría la mayor importancia. San Agustín afirmaba que la potencia de

\footnotetext{
${ }^{31}$ Elias Norbert, El proceso de la civilización. Investigaciones sociogenéticas y psicogenéticas. Recientemente, Randall Collins, Cadenas de rituales de interacción.

${ }^{32}$ Lucien Febvre, "El problema de la incredulidad en el siglo Xvi. La religión de Rabelais".
} 
ver excede a los otros sentidos corporales, ya que nos enseña más diferencias de las cosas porque es el más “espiritualizado" y mejor capacitado para aprehender las especies de los objetos. 33 "Los ojos de la carne -continúa el obispo africano- sin el alma espiritual son los ojos de los animales" . ${ }^{34}$ En la Edad Media carecía de interés ver sólo al ojo en sí mismo, sino que se contemplaba a partir de un proceso dinámico en el que la vista estuviese entrelazada con el alma de quien observaba. ${ }^{35}$

El ojo del cuerpo se une al ojo del alma en una relación en la cual la imagen impresa en la pupila se ve reflejada en la imagen guardada en la memoria del que ve; ella mueve a reconocer y a buscar la verdad y el bien. La imagen estampada en el ojo es un elemento activo (imagines agentes) en el proceso de conocimiento. ${ }^{36} \mathrm{El}$ acto de ver era trinitario: la imagen visible del cuerpo, su imagen impresa en el ojo, y la atención fija en el objeto que se observa. Las imágenes generadas por él respondían al siguiente orden: de la imagen del cuerpo visible nace la imagen en el ojo; de ésta nace otra imagen en la memoria y, de esta última, una tercera en la mirada del pensamiento. Lo que se percibe del ojo no es lo que el ojo ve por sí; es la reproducción y combinación de lo que la Trinidad del alma (memoria, voluntad y entendimiento) ha recogido de la realidad. ${ }^{37}$

El conocimiento sensible es acompañado por otra condición. La estética de Hugo de San Víctor (siglo XIII), basada en San

${ }^{33}$ San Agustín, De Trinitate, XI, 1-2.

${ }^{34}$ San Agustín, De Trinitate, XI, 1-5. Para el Obispo de Hipona, a la consideración sobre la dignidad espiritual del ojo se ańade la potencia física de recibir (antes que los demás sentidos) las sensaciones de los objetos distantes y cercanos y no depender para ello de ningún movimiento, prolongación o sucesión para que la especie se le represente al instante. (Ibidem, XI, 2).

${ }^{35}$ En Mateo 6, 22-23 y en el Evangelio según San Lucas aparece la referencia al ojo, la luz y la oscuridad, con evidente significado simbólico referido al alma y a la Luz de Dios.

${ }^{36}$ José Antonio Maraval, "La disputa del oído y de la vista”, pp. 221 y ss.

${ }^{37}$ Fernando Delmar, El ojo espiritual. Imagen y naturaleza en la Edad Media, pp. 21 y ss. 
Agustín, reconoce en el hombre una doble naturaleza: por dentro está dotado de entendimiento, orientado a la contemplación de lo invisible; por fuera, poseedor de "sensibilidad que goza en la contemplación del mundo visible". ${ }^{38} \mathrm{El}$ entendimiento encuentra en los bienes invisibles su fruto y placer, así como la sensibilidad descubre en los bienes sensibles satisfacción. Sin embargo, cuando el ojo se complace en lo exterior y de una manera desordenada en las formas sensibles, el ojo del espíritu se mancha por dentro con el "lodo de innumerables representaciones y placeres". ${ }^{39}$ Lo incorpóreo y lo inmaterial están más allá de la sensación y de la imaginación. Es por el alma y en el alma que son conocidas. ${ }^{40}$

Por otra parte, santo Tomás de Aquino colocó a lo real como fuente de conocimiento al considerar que el ser humano no podía acercarse a lo inteligible sin el dato sensible. Para Gilson, el pensamiento medieval tuvo la necesidad vital de mantener intacto el valor inteligible del orden sensible. ${ }^{41}$ Lo sensible y lo invisible están relacionados con la memoria. ¿De qué manera es concebible llegar simultáneamente al recinto de la memoria a través del ojo y del oído? Según Richard de Fournival, obispo de Amiens en el siglo XIII y autor de Roman d'Ablandane, es factible gracias al hecho de que la memoria, guardiana de los tesoros que el espíritu ha conquistado, por la excelencia de su intelecto hace presente aquello que pertenece al pasado, a la historia.

El poder de la memoria es hacer presentes los hechos ya ocurridos. La fuerza de la imagen reside en que la voluntad de recordar procede de las imágenes contenidas en la memoria; la pictura estimula la memoria en beneficio de la historia. Las imágenes avivan el entendimiento, reconocen los modelos grabados en la memoria y mueven hacia el bien. La ideología medieval que incorporó lo

\footnotetext{
${ }^{38}$ Idem.

${ }^{39}$ Delmar cita en esto a Taylor, Didascalion of Hugh of Sr Victor: A Medieval Guide to the Arts, p. 75.

${ }^{40}$ San Agustín, De Triniatate, XI, cap. 3.

${ }^{41}$ Étienne Gilson, El espiritu de la filosofía medieval, p. 238.
}

\section{2 / Óscar Fernando López Meraz}


visible e invisible, los sentidos y la memoria, encontró en la imagen a uno de sus principales caminos. Para la filosofía medieval, la imagen fue el único intermediario posible entre la realidad y su representación, entre el mundo y el alma. Pero la imagen también deja espacio para la imaginación. ${ }^{42}$ Cada época tiene su forma de ver y lo que ve es -en gran medida- lo que imagina que ve.

En América, Gonzalo Fernández de Oviedo en su Historia general y natural de las Indias declara su base epistemológica y categoría de verdad en las que funda y valida su quehacer de historiador natural. En ellas se fusionan "lo visto por los ojos" o "lo visto y lo vivido" ${ }^{43}$ Después establece el criterio del relato que el historiador o cronista recogía mediante el oído de un testigo presencial y directo de un hecho natural, de un suceso histórico o de un fenómeno social. Lo leído sería el último elemento, y estaría integrado por la tradición (teorías y obras, por ejemplo), por la cual el sujeto de conocimiento del siglo xv y aun del XVI cumplía las funciones de comparar, probar y validar su propio saber.

En el caso novohispano se planteó la necesidad de hacer visible lo invisible, y el camino seguido para ello fue el registro ("pre") "etnográfico" evangélico, mismo que también cumplió con el objetivo instrumental de la denuncia para desenmascarar los rituales

${ }^{42}$ Le Goff sitúa el territorio de lo imaginario con respecto a tres campos: el de la representación, el de lo simbólico y el de lo ideológico. Lo imaginario -diceforma parte del campo de la representación, y ocupa allí "la parte de la traducción no reproductora, no simplemente transpuesta en imagen del espíritu, sino creadora, poética en el sentido etimológico". Sin embargo, si ocupa una fracción del territorio de la representación, "lo imaginario lo desborda". Con respecto a lo simbólico, afirmó que la dimensión de lo imaginario está presente en todo símbolo en la medida en que éste, al mismo tiempo que remite a un sistema de valores subyacentes, también hay en él significaciones que escapan a lo social. Entre lo imaginario y lo ideológico las fronteras son también difíciles de precisar; lo ideológico sería algo así como el sentido impuesto a la representación por una cierta concepción del mundo, la cual lo encuadra en un marco preconstruido. Juan Camilo Escobar, Lo imaginario. Entre las ciencias sociales y la historia, p. 9, cita para esto el Prefacio de El imaginario medieval, de Le Goff.

${ }^{43}$ Fernández de Oviedo, Historia general, p. 11. 
satánicos indígenas. El religioso centró en su mirada el poder de la descripción para calmar la paranoia cristiana y organizar la semiótica evangelizadora. En los textos desfilan prácticas confusas, violentas y demoníacas que esperan ser identificadas por los ministros con el fin de castigarlas y extirparlas.

Esta interacción, entre lo conocido empíricamente y lo registrado, desarrolló la construcción del conocimiento en clave de representaciones simbólicas que eran comunicadas. El conocimiento se articulaba con base en la retórica que creaba los vínculos mentales necesarios para la incorporación y creación de redes de sentido, permitiendo ampliar la comprensión de los valores y conocimiento cristianos. La retórica no sólo funcionaba para persuadir sino, sobre todo, para la composición y creación de "localidades mentales" con el fomento de imágenes mentales, y su relación simbiótica con imágenes y palabras leídas, vistas u oídas. ${ }^{44}$

Motolinía, para demostrar la veracidad de su relato, incluye en su testimonio muchos detalles:

En lo más eminente de este patio hacían una gran cepa cuadrada y esquinada, que para escribir esto medí una de un pueblo mediano que se dice Tenayuca y hallé que tenía cuarenta brazas de esquina a esquina [...] y como la obra iba subiendo, íbase metiendo adentro, y de braza y media o de dos brazos en alto iba haciendo y guardando unos relejes metiéndose adentro, porque no labraban a nivel; y por más firme labraban siempre para adentro, esto es, el cimiento ancho, y yendo subiendo la pared iban ensangostando; de manera que cuando iban en lo alto del teucalli hablan ensangostádose y metiéndose adentro, así por los relejes como por la pared hasta siete o ocho brazas de cada parte; quedaba la cepa en lo alto de treinta y cuatro o treinta y cinco brazas. $^{45}$

${ }^{44}$ Carruthers, The Craft of Thought, op. cit., p. 10.

${ }^{45}$ Toribio de Benavente (Motolinía), Historia de los indios de la Nueva España, Tratado Primero, cap. 12. 
El fraile observa, mide, prueba y compara. Más adelante ve, cuenta y comprueba varias veces las diferentes alturas del teucalli de Tezcuco y el de México, y llega a la conclusión de que el primero tiene cinco o seis gradas más que el otro. Pero lo de verdad importante es la comparación que hace entre el "templo del demonio" y la capilla de San Francisco, siendo ésta de mucha más "ventaja" que aquél. La cristiandad era demostrablemente superior. Incluso para los nuevos feligreses era observable y por ello asistían por miles a recibir el bautizo. En una procesión de Jueves Santo, el de Benavente registra en su Historia: "en una parte son cinco o seis mil, y en otro diez y doce mil". Entre tal muchedumbre, el ojo del fraile observa a un cojo "que era cosa para notar, porque tenía secas ambas piernas de las rodillas para abajo, y con las rodillas y la mano derecha en tierra siempre ayudándose, con la otra se iba disciplinando, que en sólo andar ayudándose con ambas manos tenía bien qué hacer”. ${ }^{46}$

Ver lo trascendente no era una cualidad que poseían todos los habitantes de la Nueva Espańa. Fue más bien un acto exclusivo de los vencedores, y al no contar los naturales con esa capacidad no pudieron recuperar sus tierras por tener cegado su entendimiento. Así lo dejó escrito Motolinía:

Aunque los españoles conquistaron esta tierra por armas, en la cual conquista Dios mostró muchas maravillas en ser ganada de tan pocos una tan gran tierra, teniendo los naturales muchas armas, así ofensivas como defensivas de las de Castilla; y aunque los españoles quemaron algunos ídolos, fue muy poca cosa en comparación de los que quedaron, y por esto ha mostrado Dios más su potencia en haber conservado esta tierra con tan poca gente, como fueron los españoles; porque muchas veces que los naturales han tenido tiempo para tornar a cobrar su tierra con mucho aparejo y facilidad, Dios les ha cegado el entendimiento. ${ }^{47}$

\footnotetext{
${ }^{46}$ Motolinía, Historia de los indios, op. cit., Tratado Primero, cap. 13.

${ }^{47}$ Idem.
} 
Otro asunto que destaca en los documentos de la época, es la mención de metáforas relacionadas con la temperatura. Fray Toribio utiliza este recurso para explicar que los indios han quedado "fríos" durante los primeros cinco años (otra vez el dato señala la experiencia y el haber estado ahí, aunque él llegó casi tres años después, en 1524, de haberse dado la derrota de México-Tenochtitlan) del dominio español. A diferencia de los naturales, los conquistadores tenían un "corazón grande y vivo como fuego". Por su parte, el también franciscano Jerónimo de Mendieta encontrará en el "poco calor" de las nuevas almas cristianas algo muy favorable para la conversión cristiana debido a la falta de cólera y flema. Esta acción le parece al autor de la Historia eclesiástica indiana algo que padecen los frailes con los españoles porque son "coléricos". ${ }^{48}$

Pero no sólo la vista participó en el "conocimiento" del otro. El oído también se hizo presente en el proceso de evangelización. El ruido existente en México impidió a los frailes enseńar, y lugares como "Quautitlan” y “Tepusticlan” fueron elegidos para tal acción, y pronto el silencio y los sonidos agradables se convirtieron en indicios de la acción angelical. Motolinía "presenció" esto, y registró cómo don Francisco, indio deseoso de conocer a Dios, "por la laguna oyó un canto muy dulce y de palabras muy admirables, las cuales yo vi y tuve escritas y muchos frailes las vieron y juzgaron haber sido canto de ángeles" ${ }^{49}$

Si el ruido en Tenochtitlán resulta insoportable, es por obra del demonio que se resiste a dejar su señorío; al menos eso parece implícito en los relatos franciscanos. De manera clara y explícita se le acusa al enemigo del género humano, quien construye una sonoridad inteligible para los varones de Cristo. Dice Sahagún:

\footnotetext{
${ }^{48}$ Gerónimo de Mendieta, Historia eclesiástica indiana, t. II, libro IV, cap. XxI ${ }^{49}$ Motolinía, Historia de los indios, op. cit., Tratado Primero, cap. 15.
} 
Costumbre es muy antigua de nuestro adversario el demonio de buscar escondrijos para hacer sus negocios, conforma a lo del Santo Evangelio que dice, quien hace mal aborrece la luz. Conforme a esto, éste nuestro enemigo en esta tierra plantó un bosque o arcabuco lleno de muy espesas breńas para hacer sus maldades desde él, y para esconderse en el mismo sin ser hallado, como hacen las bestias fieras, y venenosas serpientes. Este bosque o arcabuco breńoso, son los cantares que esta tierra urdió que se le hicieses y usasen en su servicio, como su culto divino y salmos de loor, así en los templos como fuera de ellos, (los cuales llevan tanto artificio, que dicen lo que quieren, y pregonan lo que él manda, y entiéndelos solamente aquellos a quién él los adereza). Es cosa muy averiguada que en la cueva, bosque o arcabuco, donde el día de hoy ese maldito adversario se esconde, son los cantares y salmos que tiene compuestos, y se le cantan sin poder entender lo que en ellos se trata, mas de por ellos que son naturales y acostumbrados a este lenguaje; de manera que seguramente se canta lo que él quiere, sea guerra o paz, sea loor suyo o contumelia de Cristo, sin que de los demás puedan entender cosa alguna. ${ }^{50}$

Elsa Cecilia Frost, en una explicación sobre el recurso a los razonamientos providencialistas por parte de los colonizadores españoles como medio para superar el problema de la alteridad radical que suponía la existencia de los habitantes nativos americanos, afirmo: "América entró [...] de la mano del Demonio a la historia universal". ${ }^{51}$ Atendiendo a lo que consiguieron en sus crónicas misioneros como Bernardino de Sahagún, dicha frase podría ser enunciada en los siguientes términos: "América entró de la mano del ruido", para referir el modo en que fue consignada por escrito una de las primeras experiencias auditivas de los colonizadores dentro del nuevo mundo sonoro.

${ }^{50}$ Bernardino de Sahagún, Historia general de las cosas de la Nueva España, "Confutación”, libro I.

${ }^{51}$ Elsa Cecilia Frost, Este nuevo orbe, p. 25. 
Advirtamos, sin embargo, que la necesidad de Bernardino de Sahagún de recurrir a adjetivaciones de carácter demoníaco para dar cuenta de la experiencia auditiva vivida, representa tan sólo una primera etapa en el proceso cognitivo o de donación de forma para el nuevo ámbito de sonidos. ${ }^{52}$ En tal etapa, el cronista encuentra imposibilidades para comprender el sentido de esos cantos: obscuros, impenetrables.

Por otra parte, la descripción de las características de lo naturales involucró risas, admiración, emoción, cuando se daban avances en el proceso de conversión; mientras que desagrado, rechazo, temor y desesperación en momentos en que la fe no estaba bien cimentada y el diablo, según la lectura de los religiosos, se volvía dueño de las almas indígenas. Las imágenes debían estar íntimamente conectadas con las emociones, como sucedió en la representación de la expulsión de Adán y Eva del paraíso que nadie "lo vio que no llorase muy recio", 53 de tal forma que "el espectador indígena veía a los protagonistas fingir el terror, el espanto, la fuga". ${ }^{44}$

En esto se pueden diferenciar las obras de Motolinía y Sahagún quienes, por lo demás, planeaban la conversión desde diferentes ángulos. Mientras que el primero desarrolla una edad dorada, el segundo, al igual que Mendieta, no ven con mucho optimismo la evangelización. Tanto la Historia general como la Historia eclesiástica cobran sentido en esta clave. Esas apreciaciones, como el horror de los ritos mesoamericanos (ofrecimiento al sol de corazones de individuos, antropofagia, sodomía, etcétera), se van meditando a la hora de trasladarlas a la página, y en ese proceso la

52 Un interesante estudio sobre lo sonoro es la tesis de maestría "La dimensión de lo sonoro en la construcción del Ethos barroco americano", escrita por Elías Israel Morado Hernández.

${ }^{53}$ Motolinía, Historia de los indios, op. cit., p. 106.

${ }^{54}$ Ibidem, p. 111. Algunos ejemplos de estas magnificas representaciones en Serge Gruzinsky, Guerra de las imágenes. De Cristóbal Colón a Blade Runner (1492-2019), sobre todo el capítulo III. 
memoria hace su trabajo: no pierde su viveza lo experimentado y se agregan otros elementos para hacerlas más comprensibles por medio de comparaciones, analogías e inversiones (con referentes grecorromanos y moros, por ejemplo).

El cuerpo del indio será uno de los espacios en los que mejor se observe la construcción de la otredad con acento de la memoria y con ella en todo un proceso histórico diacrónico y sincrónico deseoso de manifestar al natural, pero siempre cercano a ideas (pre)cristianas. En el siguiente apartado se desarrollará cuál fue la perspectiva desde la cual los franciscanos observaron al cuerpo, participando de una "teoría” al respecto, y cómo fueron construyendo lo que llamaremos "buenos cuerpos" manteniendo la clave simbólica con la que iniciamos este trabajo en la que se inventan seres corporales más próximos a los valores cristianos que a los mesoamericanos.

\section{TEORÍA DEL CUERPO Y CONSTRUCCIÓN CORPÓREA} FRANCISCANAS

Los franciscanos desarrollaron una teoría del cuerpo en la que existían puntos de encuentro con la lascasiana (basada en Aristóteles, Avicena, Alberto Magno y otros). Entre algunas de las coincidencias se pueden mencionar la influencia que tienen los astros en los seres humanos, como lo afirmó Sahagún, o cómo el ambiente físico influía en la naturaleza humana, ${ }^{55}$ o la comprensión del natural como dulce y su gran disposición y habilidad para las artes u oficios.

Pero también hubo diferencias importantes. Mientras el dominico considera "sanguíneos" a los indios, Motolinía los califica,

${ }^{55}$ Por ejemplo, los hombres nacidos o que vivían en la zona tórrida eran considerados más fuertes e inclinados a pecar por pereza y lujuria, mientras que los habitantes de zonas templadas estarían más predispuestos a vencer a los vicios y tentaciones. Véase el capítulo 4 de Andrés de Olmos en su Tratado de pecados capitales, en especial el apartado acerca de los pecados de la gula y de la pereza.

Memoria, experiencia y cuerpo en crónicas franciscanas del siglo xvı / 39 
después de la derrota de Tenochtitlán, como "fríos". ${ }^{56}$ Esta condición los incorporaría a los humores de la bilis negra y la flema; es decir, posiblemente, una combinación entre lo triste y lo perezoso. Cinco años fue el tiempo que tardaron los indios en "despertar" para construir iglesias y recibir sacramentos, lo que fue considerado, si no un asunto milagroso, sí uno cercano al milagro.

También, si para fray Bartolomé la suavidad del clima permitía que el temperamento sexual de los indios novohispanos fuera templado y poco entregado a los extremos carnales, ${ }^{57}$ Sahagún opinó que el clima templado y sin inviernos, conjuntado con cierto orden estelar, producían justo el efecto contrario al que suponía el dominico. Incluso, fray Bernardino fue más lejos: para él, la tierra incitaba una enorme sensualidad en los cuerpos, lo que significó, según él, el fracaso en los intentos por convertir a los alumnos del colegio de Santa Cruz de Tlatelolco en castos sacerdotes.

Además, estaba convencido a plenitud de que la fuerza "sensualizante" del clima era tan poderosa, que arrasaba con los españoles emigrados, quienes en poco tiempo empezaban a dar rienda suelta a sus inclinaciones carnales, al igual que los nativos. ${ }^{58}$ Mendieta coincide con Sahagún al advertir la "fogosidad" de esta tierra y que de ella nadie se libraba. En su opinión, incluso los primeros francisanos podían ser presa de tal condición, por lo que no tomaban vino, en parte por ser muy caro, "pero también porque en esta tierra es fuego y enciende el cuerpo demasiadamente". ${ }^{59}$

Además, en el día a día, varias prácticas que tenían como centro al cuerpo de los naturales no coincidieron con el esquema cristiano virtud/vicio (o pecado). En algunos casos no sólo se trató del rechazo al pecado, sino lo que consideraron sobrevivencia, y quizá revitalización, de la idolatría. Un cuerpo adornado, por

\footnotetext{
${ }^{56}$ Motolinía, Historia de los indios, op. cit., Tratado II, Primer capítulo.

${ }^{57}$ Bartolomé de las Casas, Apologética historia, cap. 36, t. I, pp. 186-191.

${ }^{58}$ Sahagún, Historia general, op. cit., libro 10, cap. 27.

${ }^{59}$ Mendieta, Historia eclesiástica indiana, op. cit., libro 3, cap. 31.
} 
ejemplo, sería rechazado por considerarlo soberbio, pero también por promover o actualizar la memoria de la antigua fe, idolátrica y demoníaca.

La relación entre idolatría y enfermedad es evidente en los relatos franciscanos durante todo el siglo xvi. Olmos, en su Tratado de hechicerías y sortilegios, afirma: "[...] tocando la materia de manera que avese y no emponzońe a los leyentes o oyentes porque vana es la medicina que más daña que cura y más enficiona que sana; y que antes mata que da la vida” ${ }^{60}$ Sahagún, por su parte, realizó su famosa analogía entre el médico de cuerpos y el de almas. ${ }^{61}$ Destaca que los comentarios de ambos religiosos sobre las claras relaciones entre cuerpo-enfermedad-médico-salvación se ofrezcan en los prólogos de sus obras, lo que indicaría la claridad del marco interpretativo que dominaría sus textos.

Otro de los tropos más recurridos por los frailes para relacionar la fe cristiana con lo "bueno", y la vida precortesiana con lo "malo", es el del sodomita. La existencia permanente de ese pecado antes de la llegada de los religiosos sirvió para recordar la implantación de la fe cristiana. Pero lo que aquí interesa destacar es cómo el discurso franciscano presenta similitudes entre la perspectiva negativa del mundo cristiano sobre el tema y las del mundo mesoamericano. En este sentido, no extrańa que Jerónimo de Mendieta sostuviera que muchos caciques de la Triple Alianza aborrecieran el pecado nefando y, por tal motivo, "mandaba[n] matar á los que lo cometian". ${ }^{62}$ En opinión de los religiosos, los sodomitas, las íncubas (mujeres que se "deleitaban" con otras mujeres), los varones que se vestían de hembras y las mujeres que lo hacían como hombres eran perseguidos por los señores y ajusticiados.

\footnotetext{
${ }^{60}$ Olmos, Tratado de hechicerías y sortilegios, op. cit., Prólogo, p. 3.

${ }^{61}$ Sahagún, Historia general, op. cit., prólogo al libro primero: "Los predicadores y confesores médicos son de las ánimas".

${ }^{62}$ Mendieta, Historia eclesiástica indiana, op. cit., libro II, cap. vI.
} 
La ley natural era conocida por los indios, incluso antes de la llegada de los frailes. Por ello Motolinía, al describir los usos matrimoniales indígenas, intenta demostrar que los indios usaban el derecho natural, el jus gentium et civile, castigaban los delitos repugnantes a la ley divina. Nuestro franciscano señala que por el derecho civil y en atención a permitir un mal menor, los indígenas permitían la prostitución; a favor de la ley divina, afirma que en el mundo prehispánico castigaban "todo lo que es contra los diez mandamientos de Dios", describe particularmente las penas que los indígenas imponían a quienes cometían sodomía y adulterio y menciona que tenían castigos contra el homicidio y el hurto. ${ }^{63}$

En oposición a las crónicas de los conquistadores, los frailes defendieron la "honestidad" de los indios mexicanos. "Los que cometían el crimen pésimo, agente y paciente, morían por ello; y de cuando en cuando la justicia los andaba a buscar, y hacían inquisición sobre ellos para los matar, que bien conocían qué tan nefando vicio contra natura, porque en los brutos animales no lo veían". ${ }^{64}$ Además de la "Ley", los naturales habrían desarrollado otro tipo de acciones para evitar la sodomía. Los frailes hablan de mujeres ataviadas, seductoras y peligrosas; criticadas, pero toleradas; mal necesario para preservar la virginidad de las doncellas y la paz de las repúblicas indianas, para evitar males mayores y vicios de sodomía. A pesar de ello, Sahagún afirma: "y los que son notados del vicio nefando, sin vergüenza la mascan, y tienénlo por costumbre andarla mascando en público; y los demás hombres, si lo mesmo hacen, nótalos de sodométicos". ${ }^{65}$

Si la noción del mal cuerpo se relacionó con prácticas idolátricas y bestiales, como la sodomía, señales del pasado necesario de borrar, también se construyeron tropos relacionados con los "buenos" cuerpos. Entre ellos destacan los niños que sirvieron de

${ }^{63}$ Fray Toribio Motolinía, Memoriales, 2a parte, cap. 5.

${ }^{64}$ Ibidem, II, 16.

${ }^{65}$ Sahagún, Historia general, op. cit., libro 10, cap. 24.

42 / Óscar Fernando López Meraz 
denunciantes de la idolatría, como sucedió con Cristóbal, Antonio y Juan, en Tlaxcala, quienes habrían sido asesinados por la resistencia india ante la segura persecución de sus prácticas religiosas. A partir de ello, se extendió una gran devoción indígena a los niños mártires de Tlaxcala. Fray Toribio lo registró en las páginas de su obra, ${ }^{66}$ y el tema recibió una amplia difusión en el mundo indígena, además de ser objeto de cuadros y obras de teatro hasta principios del siglo XIX.

El caso representaría un conflicto generacional que no se hizo esperar. Motolinía enuncia algunas de las características de estas confrontaciones en esa primigenia época, donde se enfrentaron, sin duda, padres contra hijos:

estos señores y ministros principales [los mexicas paganos] no consentían la ley que contradice a la carne, lo cual remedió Dios matando mucho de ellos con las plagas y enfermedades ya dichas y de otras muchas y otros se convirtieron; y como de los que murieron han venido los señoríos a sus hijos, que eran de pequeños bautizados y criados en la casa de Dios; de manera que el mismo Dios entrega sus tierras en poder de los que en Él creen; y lo mismo han hecho contra los opositores que contradicen la conversión de los indios por muchas vías. ${ }^{67}$

Un síntoma inequívoco del agrado que tenía Dios hacia los niños indios, es la resurrección de uno de ellos. Antes de que amortajasen al niño Ascencio,

mucha gente lo vio estar frío y yerto y defunto. Ya que lo querían llevar a la iglesia dijeron los padres que siempre su corazón tenia fe y esperanza en el gloriosos padre S. Francisco, que les debía alcanzar de Dios la vida de su hijo. Y como al tiempo que lo querían llevar tornasen a orar e invocar con devoción a S. Francisco,

${ }^{66}$ Mendieta, Historia eclesiástica indiana, op. cit., también lo hizo en libro III, cap. XXVII.

${ }^{67}$ Motolinía, Historia de los Indios, op. cit., Tratado segundo, cap. I.

Memoria, experiencia y cuerpo en crónicas franciscanas del siglo XVı / 43 
súbitamente se comenzó a mover el niño, y de presto aflojaron y desataron la mortaja, y tornó a vivir el que era muerto, y esto sería a la misma hora de vísperas. Del cual hecho los que allí se hallaron presentes para el entierro (que eran muchos) quedaron atónitos y espantados, y los padres del niño en gran manera consolados. Hiciéronlo luego a saber a los frailes de S. Francisco de México, y fue allá el famoso lego Fr. Pedro de Gante [...] él y su compañero vieron al niño vivo y sano, y certificados de sus padres y de otros testigos dignos de fe de lo que había pasado. ${ }^{68}$

No es casual que la figura del niño sea tan destacada en las crónicas franciscanas. Este sujeto fue insertado desde la baja Edad Media en el ámbito de la salvación, en gran parte promovido por la exaltación de la infancia de Jesús, y ensalzado en muchas ocasiones por el sufrimiento del martirio. La iconografía de los siglos XIII al XVI es testigo de la enorme veneración al niño Jesús y el desarrollo del culto a los Santos Inocentes. ${ }^{69}$

La violencia es compañera casi imprescindible de este proceso. La sangre de los menores y la impotencia de sus madres en diferentes escenas sangrientas son protagonistas. El significado de la sangre es trascendental. Ella, para el caso de los niños mártires, borraba el pecado original, mientras que los Inocentes corroboraban la premonición de que la Iglesia de Dios sería fundada con sangre. Para fortalecer esto, se actualizan episodios fundadores, como el martirio de niños durante las persecuciones romanas. Posiblemente, el mejor ejemplo de esta reinvención de la niñez santa sean los santos Justo y Pastor, niños de Ávila decapitados en tiempos de Diocleciano, muy venerados que hasta la época del Renacimiento se destacó su carácter "infantil” ${ }^{70}$

\footnotetext{
${ }^{68}$ Mendieta, Historia eclesiástica indiana, op. cit., libro III, cap. LXI.

${ }^{69}$ Niños que fueron decapitados por el rey Herodes en Belén para eliminar el peligro de ser destronado por el recién nacido rey salvador.

${ }^{70}$ Antonio Rubial, "El tirano, el judío y el idólatra. La hagiografía de los mártires niños y sus malvados verdugos en España y Nueva España”, p. 4.
} 
Esto nos lleva a preguntarnos sobre la invención de un cuerpo mesoamericano en las crónicas franciscanas. Algunas posibles claves de esta "conversión prehispánica" en el discurso misionero son algunas descripciones con trasfondo occidental-cristiano en lo correspondiente al cuerpo. Veamos algunas. Sahagún pone en boca de los ancianos palabras para cuidarse de las mujeres:

[al comer] mayormente te debes guardar en esto de los que te quieren mal; y más de las mujeres, en especial de las que son malas mujeres; no comerás ni beberás lo que te dieren, porque muchas veces dan hechizos en la comida o en la bebida [...] para provocar la lujuria, y esta manera de hechizos no solamente empece al cuerpo y al ánima, pero también mata porque se desaina el que lo bebe, o lo come, frecuentando el acto carnal hasta que muere. $^{71}$

El cuidado del cuerpo para el varón no sólo estaba relacionado con ser precavido con esas brujas encubiertas, sino en hacerlo consigo mismo. Esto es, alejarse de los placeres. Los "sabios" traducidos por Sahagún aconsejan: "mira que te apartes de los deleites carnales y en ninguna manera los desees; guárdate de todas las cosas sucias que ensucian a los hombres, no solamente en las ánimas, pero también en los cuerpos, causando enfermedades y muertes corporales" ${ }^{72}$

La lógica de la culpa envuelve todo el discurso comunicado por fray Bernardino a quienes deberían integrar la cristiandad indígena en lo que fue la vieja Mesoamérica. La trilogía caída, pecado y redención pertenecía a lo revelado, a lo incuestionable. Por ello, una vez reconocida la humanidad de los indios, y por tanto sumarlos a ese "drama", no resulta raro que ellos hubieran desarrollado prácticas similares a las "verdaderas". Ejemplos de ello, resultaron la práctica del bautismo y de la confesión, grandes

${ }^{71}$ Sahagún, Historia general, op. cit., libro vi, cap. XXIII.

${ }^{72}$ Ibidem, libro VI, cap. XXI.

Memoria, experiencia y cuerpo en crónicas franciscanas del siglo XVI / 45 
remedios para limpiar de los pecados. En cuanto al primero, los abuelos decían, según Sahagún:

¡Oh nieto mío, hijo mío, recibe y toma el agua del señor del mundo, que es nuestra vida, y es para que nuestro cuerpo crezca y reverdezca, es para lavar, para limpiar; ruego que entre en tu cuerpo y allí viva esta agua celestial azul, y azul clara! [...] Ruego que ella destruya y aparte de ti todo lo malo y contrario que le fue dado antes del principio del mundo, porque todos nosotros los hombres, somos dejados en su mano, porque es nuestra madre Chalchiuhtlicue. ${ }^{73}$

La confesión también se manifestó en el mundo mesoamericano en la mirada del fraile. Práctica considerada obligatoria desde el IV Concilio de Letrán (1215-1216) para la cristiandad, entre los naturales también se efectuaba. Sin embargo, era necesario explicar esta presencia. La luz natural que Dios deposita en todo ser humano debía ir acompañada de más elementos. Bautismo, confesión y otros sacramentos son observados en la vida indígena por los soldados de Cristo, pero no son las versiones correctas. Para explicarlo, en la época se hablaba del paralelismo entre la iglesia de Dios y la iglesia del demonio, quien deseaba ser venerado y por lo tanto tenía sus propios templos.

Mendieta no dudó en adjudicar una razón sobrenatural a las similitudes precortesianas, y culpa de ellas al diablo. ${ }^{74}$ Esta posición responde a la denominación del demonio como "Mono de las obras de Dios” por parte de San Buenaventura. Es tal la aspiración de Luzbel que "quiere contrahacer las obras de Dios, pero no siempre puede todo lo que quiere, sino lo que Dios le da lugar, y

${ }^{73}$ Sahagún, Historia general, op. cit., libro vi, cap. XxxviI.

${ }^{74}$ Aunque sin citarlo explícitamente, parece que Mendieta se apega a lo que se afirma en el Salmo 95, 5: Quoniam omnes dii gentium daemonia (todos los dioses de los pueblos son demonios). Vulgata, Salmo 95, 5. En las versiones modernas aparece bajo el número 96 y el texto tiene otro sentido. En otra parte de la Biblia se afirma que la adoración de los dioses paganos es obra de los demonios (Lev. 17, 7). 
permiso". ${ }^{75}$ Esta idea también fue utilizada por teólogos del siglo XVI, que se ocuparon de los procesos de brujerías y al analizar lo que en ellos se contaba advirtieron el interés del demonio para reproducir, invirtiendo, los sacramentos de la Iglesia y convirtiéndolos en execramentos.

La soberbia hará imitar y pervertir el culto a Dios. La mímesis lo cubrirá todo: sacerdocio, templos, sacramentos, características de la Virgen y un pronunciado etcétera. ${ }^{76}$ Mendieta ve con claridad los sacramentos cristianos deformados por el demonio y sus ministros. Citamos ampliamente:

No se contentaba el demonio, enemigo antiguo, con el servicio que éstos le hacían en la adoración de cuasi todas las criaturas visibles, haciéndole de ellas ídolos, así de bulto como pintados, sino que además de esto los tenía ciegos en mil maneras de hechicerías, execramentos y supersticiones. Y hablando primero de los execramentos que ordenó en su iglesia diabólica, en competencia de los Santos Sacramentos que Cristo nuestro Redentor dejó instituidos para remedio y salud de sus fieles en la Iglesia católica; por el contrario, para condenación y perdición de los que le creyesen, dejó el demonio esto tras sus señales y ministerios que pareciesen imitar a los verdaderos misterios de nuestra redención. Entre los cuales el primero era a manera de baptismo [...] También tenían alguna manera de confesión delante de sus dioses [...] También usaban alguna manera de comunión o recepción de sacramento [...] Tuvieron también una manera como de agua bendita, y ésta bendecía el sumo sacerdote. ${ }^{77}$

${ }^{75}$ Julio Caro Baroja, Las formas complejas de la vida religiosa, pp. 71 y ss. El origen de esta idea se puede basar en la consideración que hace Justino Mártir sobre los demonios. Para Justino, los demonios advierten las palabras de los profetas, pero "no lo entendieron exactamente, sino que remedaron como a tientas lo referente a nuestro Cristo". Elsa Cecilia Frost, Historia de Dios en la Indias, pp. 87-88.

${ }^{76}$ Mendieta, Historia eclesiástica indiana, op. cit., libro. II, cap. IX.

${ }^{77}$ Ibidem, libro. II, cap. XIX. 
Fray Jerónimo construye este ejercicio para ayudar a afianzar la fe cristiana ubicada lejos del optimismo de Motolinía. Para contribuir a una evangelización profunda intenta explicar a los nuevos catecúmenos que han sido engańados, pero sólo parcialmente. Los preceptos son correctos, pero han sido invertidos. El tránsito hacia la cristiandad no resultaría para los indios tan difícil.

\section{ConClusión}

Los frailes franciscanos intentaron cumplir intereses específicos de su misión evangelizadora en sus crónicas. Alejados de intereses positivistas por contar "las cosas como fueron", comunicaron en clave simbólica sus experiencias supeditándolas a la memoria occidental-cristiana. El haber estado ahí observando, escuchando, contando, corroborando se manifiesta como un rasgo que el discurso exige para ofrecerse como Verdad en lo escrito.

En ese proceso, ser testigo en exclusiva encuentra sentido por medio de su incorporación al canon, donde la autoridad bíblica es la más importante y se acompaña de discursos teológicos, narraciones grecorromanas, referencias al presente. Así, los sentidos y las emociones se presentarán sumados a la memoria trabajada en la escritura con una carga espiritual que traduce lo nuevo a lo conocido en un largo proceso desarrollado por Occidente cuando está frente al otro. Las crónicas franciscanas demuestran la intersección entre el mundo del texto y el mundo del lector originarios.

Ahí, en la página en blanco, esos esfuerzos procuraron desarrollar en los indígenas su pertenencia al tronco de Adán y, por tanto, destacar la necesidad por esforzarse para su salvación. No hay cosa más importante para los frailes que alcanzar esta meta, mas para ello resultó necesario construir la imagen de un pasado mesoamericano, con sus prácticas religiosas/morales, como antesala de la Cristiandad y, claro, comunicarla. 
Ese ejercicio estará más destinado a fundar un nuevo marco cultural indígena donde la iglesia satánica ha puesto a los naturales en conocimiento de acciones cristianas distorsionadas por el demonio. Esto resulta en una suerte de preparación para el advenimiento de Cristo, y justifica la misión franciscana, cuya tarea sería la conversión en Cristo y desenmascarar lo que el diablo ha sembrado en la espiritualidad indígena.

En ese esfuerzo, la construcción de un tiempo nuevo se convierte en un tema núcleo en el relato franciscano. Uno en el que la conciencia del pecado y la culpa se interiorice entre los indios para preparar su encuentro con Dios. El cuerpo encuentra en ello un lugar central no sólo como medio para dar a conocer al otro inventado, sino como espacio donde se manifestará la lucha contra el mal y como testigo no de la derrota ante el conquistador, sino de la victoria sobrenatural al poder descubrir la verdadera palabra. 圈

BibLIOGRAFía

Agustín, San. De Trinitate, tr. de L. Arias, t. v, Madrid, Biblioteca de Autores Cristianos, 1956.

Amodio, Emanuele. Formas de la alteridad: construcción y difusión de la imagen del indio americano en Europa durante el primer siglo de la conquista de América, Quito, Abya Yala, 1993.

Baudrillard, Jean y Guillaume Marc. Figuras de la alteridad, México, Taurus, 2000.

Benavente, Toribio de (Motolinía). Historia de los indios de la Nueva España, México, Porrúa, 1979.

- Memoriales o Libro de las cosas de la Nueva España y de los naturales de ella, ed. preparada por Edmundo O'Gorman, México, unam, 1971.

Caro Baroja, Julio. Las formas complejas de la vida religiosa, Madrid, Akal, 1978.

Carruthers, Mary. The Craft of Thought, Meditation, Rhetoric, and the Making of Images, 400-1200, Cambridge, Cambridge University Press, 2000.

Memoria, experiencia y cuerpo en crónicas franciscanas del siglo xvı / 49 
Clastres, Pierre. "Entre silencio y diálogo", en Mauricio Boivin, Ana Rosato y Victoria Arribas (coords.), Constructores de otredad. Una introducción a la antropología social y cultural, Antropofagia, 2004. Disponible en: <https://antroporecursos.files.wordpress.com/2009/03/bolvin-m-rosato-a-arribas-v-2004-constructores-de-otredad.pdf $>$.

Clifford, Jamez. Writing Culture: The Poetics and Politics of Ethnography, University of California Press, 1986.

Collins, Randall. Cadenas de rituales de interacción, Barcelona, Anthropos, UAM-Azcapotzalco/UnAM-FCPys/Universidad Nacional de Colombia, 2009.

De Certeau, Michel. L'écriture de l'histoire, París, Gallimard, 1975.

Delmar, Fernando. El ojo espiritual. Imagen y naturaleza en la Edad Media, México, unAm, 1993.

Elias, Norbert. El proceso de la civilización. Investigaciones sociogenéticas y psicogenéticas, México, FCE, 1994.

Escobar, Juan Camilo, Lo imaginario. Entre las ciencias sociales y la historia, Medellín, Fondo Editorial Universidad/EAFIT, 2000. Disponible en: $<$ https://core.ac.uk/download/pdf/47236725.pdf>.

Febvre, Lucien. "El problema de la incredulidad en el siglo xvi. La religión de Rabelais", en Henri Berr (dir.), La evolución de la humanidad, Sección Tercera: El mundo moderno, V. 84, México, Unión Tipográfica Editorial Hispano-Americana, 1959, secc. 3.

Fernández de Oviedo, Gonzalo. Historia general y natural de las Indias, Salamanca, Cilus, 2000, t. I.

Frost, Elsa Cecilia. Este nuevo orbe, México, Dirección General de Publicaciones de la UNAM, 1996.

- Historia de Dios en las Indias. Visión franciscana del Nuevo Mundo, México, Tusquets, 2002.

Geertz, Clifford. El antropólogo como autor, Barcelona, Paidós, 1989.

Gilson, Étienne. El espíritu de la filosofía medieval, Madrid, Rialp,1981.

Greimas, A. J. y J. Courtés. Semiótica. Diccionario razonado de la teoría del lenguaje, Madrid, Gredos, 1982.

Gruzinsky, Serge. Guerra de las imágenes. De Cristóbal Colón a Blade Runner (1492-2019), México, FCE, 1990.

Gutiérrez, Raquel, “Acerca de la crónica”, Semiósis, núm. 24, enero-junio 1990, pp. 239-253. Disponible en: <https:/cdigital.uv.mx/bitstream/ handle/123456789/6399/199024P239.pdf?sequence $=2 \&$ isAllowe$\mathrm{d}=\mathrm{y}>$. 
Jofr, José Luis. "Todas las otredades la otredad. La construcción discursiva de 'la otredad' en el acontecimiento del 11 de septiembre de 2001 en la revista Time. Una aproximación sociosemiótica", Fundamentos en Humanidades, año v, núm. II (10), 2004, pp. 125-156. Disponible en: $<$ http://www.redalyc.org/pdf/184/18401008.pdf>.

Koselleck, Reinhart. Los estratos del tiempo: estudios sobre la historia, intr. de Elías Palti, Barcelona, Paidós, 2001.

Krotz, Esteban. "Alteridad y pregunta antropológica”, en Mauricio Boivin, Ana Rosato y Victoria Arribas (coords.), Constructores de otredad. Una introducción a la antropología social y cultural, Antropofagia, 2004, pp. 16-21. Disponible en: <https://antroporecursos.files.wordpress. com/2009/03/bolvin-m-rosato-a-arribas-v-2004-constructores-de-otredad.pdf $>$.

La Capra, Dominck. Historia en tránsito. Experiencia, identidad, teoría critica, tr. de Teresa Arijón, Buenos Aires, FCE, 2006.

Las Casas, Bartolomé, Apologética historia. Obras completas, Barcelona, Alianza Editorial, 1992.

Le Goff, Jacques, Faut-il vraiment découper l'histoire en tranches?, París, Éditions du Seuil, 2014.

Maraval, José Antonio. "La disputa del oído y de la vista", en Estudios de historia del pensamiento español, Madrid, Cultura Hispánica, 1973, pp. 220-250.

Mendieta, Gerónimo de. Historia eclesiástica indiana, 2a ed. facs., México, Ed. Porrúa, 1971.

Mendiola, Alfonso. "Relatos de la Conquista, retórica y referencia", en Gumersindo Vera Hernández, José Pantoja Reyes et al. (coords.), Los historiadores y la historia para el siglo xxi, México, Escuela Nacional de Antropología e Historia, 2006, pp. 113-146.

- Retórica, comunicación y realidad: la construcción retórica de las batallas en las crónicas de la conquista, México, Universidad Iberoamericano, 2003.

Millán, Saúl. "El sincretismo a prueba. La matriz religiosa de los grupos indígenas en Mesoamérica”, Dimensión Antropológica, vol. 23, septiembre-diciembre, 2001, pp. 33-49. Disponible en: <http://www.dimensionantropologica.inah.gob.mx/?p=655

Morado Hernández, Elías Israel. "La dimensión de lo sonoro en la construcción del Ethos barroco americano", tesis de maestría en Estudios Latinoamericanos, UNAM, 2012. Disponible en: <file:///C:/Users/EndUser/

Memoria, experiencia y cuerpo en crónicas franciscanas del siglo xvı / 5 I 
AppData/Local/Packages/Microsoft.MicrosoftEdge_8wekyb3d8bbwe/ TempState/Downloads/La_dimension_de_lo_sonoro_en_la_construc\%20(1).pdf>.

Olmos, Andrés de Tratado de hechicerías y sortilegios, ed. de Georges Baudot, México, UnAM, 1990.

- Tratado de pecados capitales, paleografía del texto náhuatl, versión española, intr. y notas de Georges Baudot, México, unam, 1996.

Ricoeur, Paul. Tiempo y narración, Madrid, Siglo xxi Editores, 2004.

Rozat, Guy. Indios imaginarios e indios reales en los relatos de la conquista de México, México, Tava Editorial,1993.

Rubial, Antonio. "El tirano, el judío y el idólatra. La hagiografía de los mártires niños y sus malvados verdugos en España y Nueva España", Revista Destiempos, núm. 28, enero-febrero, 2011, pp. 2-13. Disponible en: <http://www.destiempos.com/n28/rubial.pdf>.

Sahagún, Bernardino de. Historia general de las cosas de la Nueva España, preparada por el padre Ángel María Garibay, México, Porrúa, 2000.

Scott, J. W. "Experiencia”, La Ventana, núm. 13, 2001, pp. 42-73. Disponible en: <http://148.202.18.157/sitios/publicacionesite/pperiod/ laventan/Ventana13/ventana13-2.pdf>.

Thompson, E. P. Miseria de la teoría, Barcelona, Crítica, 1981.

Todorov. Tzvetan. La conquista de América, el problema del otro, tr. Flora Botton Burlá, México, Siglo xxi, 1987.

Viveiros de Castro, Eduardo. La inconstancia del alma salvaje, Buenos Aires, Los Polvorines/Universidad Nacional de General Sarmiento, 2018. 